\title{
Gain or Pain: Does Consumer Activity Reflect Utility Maximisation?
}

\author{
by \\ Yoonhee Tina Chang \\ School of Management, University of Bath \\ $\&$
}

Catherine Waddams Price

ESRC Centre for Competition Policy, University of East Anglia

\section{CCP Working Paper 08-15}

\begin{abstract}
Competition Authorities are introducing new informational remedies to help consumers search and switch more actively. Using a specially commissioned data set, and unique direct estimates of the gains, search and switching time which consumers anticipate, we examine the determinants of consumer activity in eight markets. We find that expected costs (and to some extent gains) do influence consumers as a utility maximising model would predict; but that their role is small, and other factors, particularly experience of switching in other markets, are also influential. We conclude that consumers' confidence in their own estimates is crucial in encouraging market activity.
\end{abstract}

February 2008

JEL Classification Codes: D12, D83, L51, L88, L98

Keywords: consumer behaviour, search and switching, informational remedies

\section{Acknowledgements:}

The support of the Economic and Social Research Council (ESRC) is gratefully acknowledged. The authors are extremely grateful to Chris Wilson for important insights and contributions; to Andrew Bugg and Hieu Tran for excellent research assistance; and to Tim Dant, Stephen Davies and Morten Hviid for very useful discussions. They also thank participants at the $23^{\text {rd }}$ Conference of the European Association of Law and Economics, and at seminars at the Centre for Competition Policy, the School for Political Social and International Studies at UEA, University of California Energy Institute and the London Business School for helpful comments. The usual disclaimer applies.

\section{Contact details:}

Catherine Waddams, ESRC Centre for Competition Policy, University of East Anglia, Norwich NR4 7TJ, UK

c.waddams@uea.ac.uk 


\section{Introduction}

Competition Authorities are imposing many so-called informational remedies, to encourage consumers to be more active in markets by searching between alternative offerings and switching suppliers when this is advantageous to them (Garrod et al, 2008). For example, in each one of the six market inquiries concerned with final consumer markets which the UK Competition Commission concluded between 2003 and 2007, informational remedies have been applied, even where the main 'Adverse Effect on Competition' was cited on the supply side. In two cases the Commission explicitly rejected a price cap, sometimes seen as a regulator's first defence against excessive prices caused by market dominance, in favour of such remedies. These usually take the form of providing more information to consumers at the time of purchase, often in narrowly prescribed formats $;^{1}$ the creation of more options or time in which consumers can change their minds or choose alternatives; ${ }^{2}$ or removal of actual or perceived barriers to switching. ${ }^{3}$ Where switching barriers were addressed, provision of consumer information was also an important aspect of the remedy package.

Such remedies are posited on the assumption that consumers will react by becoming more active as they are provided with more information, given more time to digest such details and to revisit their original purchase decision, and the barriers to switching are reduced. The success of such interventions is posited on an implicit assumption that consumer activity in markets reflects an underlying model of utility maximisation. But a growing strand of economic theory and accumulating empirical evidence suggest that consumer behaviour is much more complex than such a model suggests. If purchasers do not respond in the way which the classic economic model suggests, such remedies may be ineffective or, worse, could have perverse consequences and make the situation worse than before the remedy was imposed. For example, if giving consumers more time to investigate alternatives leads them to undertake a purchase on the basis that they (wrongly) expect to revisit the decision, but in practice they do not do so, it may lead to greater market power for firms (Silk, 2006). Similarly if consumers do not respond to reduced search and switching costs by increasing activity, but these remedies increase confidence that markets are working well, firms may be able to exercise greater market power (Waterson, 2003). Since most such remedies are costly to implement, at best they are likely to drive prices upward if they have no beneficial consequences.

In contrast, if consumers do behave as predicted by a traditional model of utility maximisation, they can indeed play an important role in supporting efficient markets. If consumers can compare alternative deals and select the one which best suits their needs, they provide a powerful incentive for firms to compete effectively. Socially damaging market power can result when consumers do not do so, either because they do not conform to the "utility maximising' model, or because they are unaware of the possibility of choosing

\footnotetext{
${ }^{1}$ Veterinary Medicines, CC 2003a; Store Cards, CC, 2006a; Home Credit, CC, 2006c.

${ }^{2}$ Extended Warranties, CC 2003b.

${ }^{3}$ Liquefied Petroleum Gas, CC, 2006b; Northern Irish Personal Bankin, CC, 2007.
} 
between alternative suppliers, when consumers face difficulty in identifying suppliers' product-price offerings (high search costs) or when consumers find it costly to change between different firms (high switching costs). ${ }^{4}$ Understanding exactly how consumer ability is impaired is vital for policymakers in several regards. Firstly, the optimal policy response may differ substantially between different types of problems. Improving consumers' access to information to reduce search costs and to improve awareness is quite different from reducing switching costs by, for example, ensuring that consumers can open and close new bank accounts and change direct debit arrangements quickly and easily. Secondly, policy may need to be targeted to specific groups of consumers if certain consumer groups are more impaired than others or if certain groups play a more important role in the market than others. Finally, the problems may only exist in certain types of markets and so it is useful to know how these decisions vary in different markets. Evidence presented in this paper can improve current policy advice on these issues by separately identifying the effect of expected search and switching costs on the behaviour of a sample of consumers across eight regulated and newly deregulated markets in the UK. The form and institutional arrangements for regulatory oversight vary considerably between the sectors examined, and our analysis provides a new perspective on such differences.

We examine the way in which consumers react to expectations about potential gain from switching supplier, and how long they anticipate it will take them to search for a better deal and to make the switch once the decision to change has been made and the new supplier identified, so that we can explore how far consumers do indeed seem to follow a utility maximising model, based on their own estimates of the potential gains and costs involved in searching.

In the next section we review the literatures on relevant recent developments in behavioural economics and on searching and switching behaviour. The model motivation and econometric method are described in section 3 , and the survey and data in section 4 . Section 5 presents and assesses the results, and section 6 draws policy lessons and concludes.

\section{Literature}

There has been increasing interest in the extent to which consumers' decisions conform to a model of a 'rational' economic agent, and the implications for competition policy, and we discuss this literature before reviewing previous empirical studies on search and switching costs. Rotemberg (2008) presents evidence that consumers have poor knowledge and awareness of prices, are often motivated by regret related to their own choices and anger at perceived unfairness in market opportunities, and have difficulty in choosing the best deal from a menu of price choices. Several papers provide empirical evidence of consumers failing to choose the best deal for themselves from a menu of tariffs, either provided by a single supplier or by competitors (Economides et al., 2006 and Miravete, 2003 for US telecoms; Agarwak et al (2006) for US

\footnotetext{
${ }^{4}$ See Baye et al (2006) for a review of the potentially anti-competitive effects of search costs, and Farrell and Klemperer (2006) for switching costs. Wilson (2006) considers the effects of the two costs when consumers may face both costs.
} 
credit cards; Lambrecht and Skiera (2006) for German internet provision; Wilson and Waddams Price (2007) for UK electricity consumers).

There are two underlying explanations for such findings. One is that consumers have a stable set of preferences, and they are maximising utility subject to their cognitive and time limitations; i.e. they are operating subject to 'bounded rationality' (Simon, 1991; Ellison, 2005). The second explanation, both for errors observed in the market place, and of apparently non rational findings from the experimental literature, is that a model of utility maximisation is fundamentally inappropriate for consumer choice (DellaVigna, 2007). Behaviour based either on bounded rationality or on an objective other than maximisation of utility functions has important implications for appropriate policy interventions.

Turning to more specific analysis of search and switching activity, two distinct streams of literature have focused on the effects of either search or switching costs in isolation, with a small set of papers considering both. Wilson (2006) suggests that before starting their search, consumers will be more deterred by expected search costs than anticipated switching costs, because any investigation involves search costs for certain, but switching costs would be incurred only if a better deal is discovered. Alternatively consumers might find the psychological costs of the switching decision more onerous that those of uncommitted searching.

Investigations into search behaviour for new products suggest that most consumers search surprisingly little. Individual level studies suggest, for example, that consumers search an average of 1.2 or 1.3 internet sites when considering buying a book or CD (Johnson et al, 2004) or approximately three dealers when looking for a new car (Moorthy et al, 1997). Recent work combines market level data with restrictions from theoretical models to recover estimates of the market distribution of search costs (Hortaçsu and Syverson, 2004; Hong and Shum, 2006). In the online market for memory chips, MoragaGonzález and Wildenbeest (2006) estimate that around 20-30\% consumers search only once, $60-70 \%$ search two or three times and only $10 \%$ search all alternatives.

The empirical effects of switching costs have been analysed in many settings, as reviewed by Farrell and Klemperer (2006). Typically, individual level analyses find that consumer demographics, often used as proxies for search and switching costs, explain little of observed switching activity (Chen and Hitt, 2002; Kiser, 2002) and that switching costs can vary between firms, a conclusion confirmed from studies using market level data (Shy, 2002; Kim et al, 2003).

Most of the studies which consider both search and switching costs use survey level data to investigate consumers' decisions and the relative effects of search and switching costs. ${ }^{5}$ Typically, the decision to switch suppliers is

\footnotetext{
${ }^{5}$ In contrast, Moshkin and Shachar (2002) introduce and implement a methodology to identify how consumers are relatively constrained by the two costs. With only the use of panel dataset of US television
} 
estimated as a function of the gains available from doing so (objectively calculated from the researchers' information about opportunities in the market); and a set of demographic and individual variables to proxy search and switching costs. Giulietti et al (2005) find that switching cost proxies appear to be the most influential factor in the decision to change suppliers for over 700 consumers in the UK gas market. While employing measures for the monetary gains available to each consumer from switching, and controlling for the possibility that some consumers were not aware of the option to switch, they find that the effects of consumers' expectations of both the time it would take to switch and of the difficulty of switching were greater than the effects of search cost proxies or demographic variables.

Pomp et al (2005) utilise a similar methodology across a series of nine different product markets in Holland. Their approach enables comparison of switching behaviour across markets while allowing for unobserved consumer effects, but is limited in that the controls for the gains available extend only to a measure of whether each consumer considered the gains to be high or not. They find that search cost factors appear to be insignificant in the decision to switch. While these two studies are useful, their results are restricted by the inability to separate the decision to search from the decision to switch. In contrast, Sturluson (2003) suggests the probability of switching is over four times higher for those consumers who have actively searched. Unlike Giulietti et al (2005), he finds that search costs exert a much larger effect than switching costs. However, this study is limited by the methodology used to construct a measure of consumers' expectations of the savings available from switching.

This paper provides an opportunity to assess the underlying model assumption of consumer rationality (even if bounded) as a basis for policy intervention. In this sense it draws on the strengths of preceding empirical work to provide a more detailed approach to consumer search and switching behaviour. To aid policymakers in understanding whether they should focus on attempts to reduce search or switching costs, like Sturluson (2002), the data allows us to identify separately the effect of expected time to search and switch. Secondly, in order to help target policy at specific types of consumers and markets, like Pomp et al (2005), we can compare behaviours and decisions of the same group of consumers across a range of different markets. In particular, by using direct estimates of consumers' expectations for both gains and, separately, for search and switching, we are able to model each decision in terms of anticipated benefits and costs more directly than in most previous attempts. This enables us to identify the extent to which such actions reflect an underlying utility maximisation model; and the effect of market and consumer characteristics separately from their role as proxies for anticipated gains and costs.

viewers' choices they show that $71 \%$ of consumers' behaviour is more consistent with the existence of search costs. 


\section{The Model, Data and Modelling}

In this section we first describe the motivation for the model we use, and then the econometric methodology.

\subsection{Motivation for Model}

Consumers maximising utility in a classic economic model would increase search and switching activity as anticipated monetary gains rose and the expected hours needed for searching and switching fell. The value of both the monetary gains and the cost of the time vary between consumers according to their circumstances, in particular their income. Respondents with higher income would be less likely to switch for given expected gains and anticipated time for two reasons. The value of the monetary gain to them would be less: and the opportunity cost of their time would be greater, raising the disincentive effect of the activity; the influence of more education (which is closely correlated with income) on the length of time taken itself should be captured in the direct measures of expected time. Other demographic variables which might affect the trade-off between expected gains and costs include age and gender, either for intrinsic reasons or as a result of targeting by firms (Giulietti et al., 2005); and consumers to whom quality is an important consideration may be less likely to switch to suppliers whose quality is unknown.

Consumers' willingness to search and switch will also depend on how confident they are in their estimates of the potential gains and costs, with a greater willingness to act (for given central expectations of gain and pain) the less variation they perceive there to be around their central estimate. This variance is likely to be lower if they have experience of switching in other markets. Similarly general knowledge about which markets are competitive may increase confidence and the probability of searching and switching.

Applying a utility maximisation model, once consumers are aware of the possibility of choosing between alternatives, they face a two-stage choice problem: firstly whether or not to search; and secondly, depending on the information obtained during such search, whether or not to switch.

Our model for consumers who are aware of the possibility of choice in any market can therefore be described as a two-stage model in which the propensity to search is given by

$\mathrm{P}(\mathrm{se})=\mathrm{a}$ (expected gain, anticipated search costs, anticipated switching costs, income, age, gender, supplier expected to match, important to trust supplier, switching in other markets, general market knowledge)

And to switch by

$\mathrm{P}(\mathrm{sw})=\mathrm{b}$ (expected gain, anticipated switching costs, income, age, gender, supplier expected to match, important to trust supplier, switching in other markets, general market knowledge)

A consumer's attitude to search and switching, and to the potential gains available, might vary between markets for several reasons. The searching and 
switching process may be less psychologically onerous for some products than for others, independently of the time consumers expect to spend; potential gains which are a very small proportion of expenditure may be regarded as less motivating than where gains represent a large share of the bill; and there may be more knowledge about some markets than others, for example because of advertising or information campaigns, so that consumers are more confident in their estimates. We therefore expect that the relationships in equations (1) and (2) might vary between markets.

\subsection{Econometric Model}

In modelling consumer switching, based on consumer utility, we follow the indirect utility function approach of Giulietti et al. (2005). However unlike Giulietti et al we do not model awareness of choice as part of the process, since the markets had all been open for several years when the survey was administered, and general awareness was high. Rather, we restrict the analysis to those consumers who were aware of choice in each market. Given that the default position is that consumers stay with their current supplier unless the expected benefit from switching exceeds the costs which they expect to incur in searching for a better deal and making the switch, we view a consumer's change of supplier as a two-stage process, encompassing firstly search, and secondly switching. We analyse this process in the eight markets, $(k=8)$, listed in the next section, by modelling the decision of a consumer to search and switch as a two-stage decision. The underlying process of search and switching decisions is represented by the latent variable model described in the following relationships,

$$
\begin{gathered}
y_{i k 1}^{*}=X_{i k 1}^{\prime} \beta_{1}+\varepsilon_{i k 1} \\
y_{i k 2}^{*}=X_{i k 2}^{\prime} \beta_{2}+\varepsilon_{i k 2}
\end{gathered}
$$

where ik indicates the ith consumer in the $k$ th market, the subscript 1 relates to the search decision and the subscript 2 to the switching decision. The error terms, $\varepsilon_{i k 1}$ and $\varepsilon_{i k 2}$ are assumed to be normally distributed but not necessarily independent of each other. The column vector $X_{i k 1}$ in equation (1) identifies the set of factors affecting the search decision and the vector $X_{i k 2}$ in equation (2) represents factors affecting the decision to change supplier. Since the two decisions are believed to be closely correlated, the initial model included the same set of variables as factors which would potentially affect search and switching decisions. The model was subsequently reduced to one with a smaller number of interaction terms by the general-to-specific approach using the Akaike's information criterion (AIC) for model selection. The model selection process and the AIC test summary are shown in Tables A2 and A3 in the appendix.

Consumers who have searched are observed as $y_{i k 1}=1$ if $y_{i k 1}^{*}>0$, and those who have switched suppliers are observed as $y_{i k 2}=1$ if $y_{i k 2}^{*}>0$. We analyse the search and switching decision process using a bivariate probit model, allowing 
some degree of correlation between the unobserved factors affecting the twostages of the decision captured in $\varepsilon_{i k 1}$ and $\varepsilon_{i k 2}$.

The likelihood function of this bivariate probit model (Greene 2002) is:

$$
\begin{aligned}
\ln L\left(\beta_{1}, \beta_{2}, \rho\right)= & \sum_{i} \sum_{k}\left\{y_{i k 1} y_{i k 2} \ln F\left(X_{i k} \beta_{1}, X_{i k} \beta_{2} ; \rho\right)\right. \\
& +y_{i k 1}\left(1-y_{i k 2}\right) \ln \left[\Phi\left(X_{i k} \beta\right)-F\left(X_{i k} \beta_{1}, X_{i k} \beta_{2} ; \rho\right)\right] \\
& \left.+\left(1-y_{i k 1}\right) \ln \Phi\left(-X_{i k} \beta\right)\right\}
\end{aligned}
$$

The joint probability that individual $i$ in the $k$ th market searches between alternative suppliers and switches to another supplier is

$$
P\left(y_{i k 1}=1, y_{i k 2}=1\right)=\Phi_{2}\left(X_{i k}^{\prime} \beta_{1}, X_{i k}^{\prime} \beta_{2}, \rho\right)
$$

where $\Phi_{2}$ is the cumulative distribution function of the bivariate standard normal and $\rho$ indicates the degree of correlation between the error terms $\varepsilon_{i k 1}$ and $\varepsilon_{i k 2}$. The unconditional probability that a consumer will search is:

$P\left(y_{i k 1}=1\right)=\Phi\left(X_{i k}^{\prime} \beta_{1}\right)$

The marginal effects of different factors on the probability of searching and switching supplier are calculated based on the probability of changing supplier, conditional on having searched around for alternative suppliers.

$P\left(y_{i k 2}=1 \mid y_{i k 1}=1\right)=\Phi_{2}\left(X_{i k}^{\prime} \beta_{1}, X_{i k}^{\prime} \beta_{2}, \rho\right) / \Phi\left(X_{i k}^{\prime} \beta_{1}\right)$

Although we obtain the marginal effects of each factor only for those who have both searched and switched supplier, $P\left(y_{i k 2}=1 \mid y_{i k 1}=1\right)$, probabilities of other combinations are predicted from the estimation, viz.: not searching and switching $P\left(y_{i k 2}=1 \mid y_{i k 1}=0\right)$; searching but not switching $P\left(y_{i k 2}=0 \mid y_{i k 1}=1\right)$; and neither searching nor switching $P\left(y_{i k 2}=0 \mid y_{i k 1}=0\right)$.

\section{The Survey and the Data}

The data we use are from a specially commissioned large scale survey administered in the summer of 2005 . The survey was conducted by Market and Opinion Research International and carried out among a nationally representative sample of 2027 adults aged 16 or over, interviewed face-toface, in-home, in 167 sampling points across Great Britain (i.e. excluding Northern Ireland). The survey used quota sampling which followed the Government Office Region's set quota on demographics (age, gender, class etc.). 
Respondents were asked which products the household consumed and paid for, from a list comprising gas, electricity, mobile phone, fixed phone line rental, national and overseas calls, broadband internet, house contents insurance, car insurance, mortgage, current bank account and piped water supply. These markets are similar in that they all require a 'relationship' between supplier and consumers which the consumer needs to sever in order to switch to an alternative provider. But they differ in the degree of homogeneity of the product and the nature of regulatory oversight, the transparency of pricing structures and the information that consumers are likely to have about the charges levied by their own suppliers and others. Respondents were then asked whether they had a choice of supplier for each product in their region, to test their awareness of competition in the market. Virtually all respondents had a choice for all products, except for water, where no choice was available. Respondents were selected if they were aware that choice was available in the relevant market and were solely or jointly responsible for making decisions on who supplied that product.

Further questions were asked about all these markets except water, gas and house contents insurance. In particular, for our purposes, respondents were asked whether they had searched around for better deals and whether they had switched supplier in each market during the previous three years (other than when moving house). They were also asked how long such search and switching had taken, or how long they would expect it to take. Questions were also asked about how much they thought they could save in each market if they shopped around. The questions posed and the construction of the variables are reproduced in the appendix.

To reduce attrition, years of education were used as a proxy for income. ${ }^{6}$ We would expect that more education would reduce the probability of switching for given monetary gain and time estimates. The direct estimates of anticipated time should have already captured the effect of education on reducing the expected time required for market activity. But those who are better educated might both find the process psychologically easier (a factor not reflected in other variables), and be more confident in their estimates, and so be more likely to search and switch.

Respondents were also asked whether they thought it important to trust their supplier in each market, to reflect potential quality concerns. The correct response to the water market question, that there is no choice of supplier, was used as a proxy for general knowledge of markets and labelled 'savvy'.

We analyse each household and market as an individual observation, i.e. we regard our data as a panel $(I \times K)$ across households $(I)$ and products $(K)$. Each such household/market observation was included only if all the relevant variables described above were known for that case. We explore the effect of this selection process after presenting the results in the next section.

Tables 1 to 4 present descriptive statistics for the whole sample.

\footnotetext{
${ }^{6} 956$ respondents (almost half the sample) either refused or responded 'don't know' to the question on income.
} 
Table 1: Levels of Awareness of Choice and Experience of Search and Switching

\begin{tabular}{|c|c|c|c|c|c|c|c|}
\hline Market & No. responsible & Aware & $\%$ & Searched & $\%$ & Switched & $\%$ \\
\hline Electricity & 1,605 & 1,476 & 92 & 439 & 27 & 370 & 23 \\
\hline Mobile phone & 1,670 & 1,595 & 96 & 458 & 27 & 370 & 22 \\
\hline Fixed phone line & 1,512 & 1,312 & 87 & 196 & 13 & 121 & 8 \\
\hline $\begin{array}{l}\text { National/overseas } \\
\text { calls } \\
\text { Broadband }\end{array}$ & 1,410 & 1,247 & 88 & 232 & 16 & 172 & 12 \\
\hline internet & 889 & 797 & 90 & 136 & 15 & 90 & 10 \\
\hline Car insurance & 1,202 & 1,139 & 95 & 409 & 34 & 304 & 25 \\
\hline Mortgage & 840 & 786 & 94 & 139 & 17 & 84 & 10 \\
\hline $\begin{array}{l}\text { Current bank } \\
\text { account }\end{array}$ & 1,759 & 1,683 & 96 & 125 & 7 & 74 & 4 \\
\hline Average across ma & rkets & & 92 & & 20 & & 14 \\
\hline
\end{tabular}

Table 2: Average Expected Savings from Searching and Switching ( $£$ per month)

\begin{tabular}{llllll}
\hline Market & number & Exp max gains & Std. dev. & $\begin{array}{l}\text { Reported } \\
\text { average bill }\end{array}$ & $\begin{array}{l}\text { Expected gains } \\
\text { /average bill }\end{array}$ \\
\hline Electricity & 518 & 7.74 & 10.40 & 35.82 & 0.22 \\
Mobile phone & 601 & 7.99 & 11.17 & 25.69 & 0.31 \\
Fixed phone line & 420 & 6.03 & 8.12 & 22.27 & 0.27 \\
National/overseas calls & 352 & 6.60 & 8.71 & 19.30 & 0.34 \\
Broadband internet & 218 & 5.69 & 6.92 & 19.63 & 0.29 \\
Car insurance & 392 & 11.97 & 16.42 & 53.90 & 0.22 \\
Mortgage & 196 & 37.89 & 43.60 & 427.89 & 0.09 \\
Current bank account & 302 & 3.66 & 9.81 & 7.32 & 0.50 \\
\hline Average across markets & & $\mathbf{9 . 3 8}$ & $\mathbf{1 2 . 6 8}$ & & $\mathbf{0 . 2 8}$ \\
\hline
\end{tabular}

Consumers expect greatest potential gains from switching in the mortgage market in absolute terms, though these are the lowest as a proportion of average spend. In terms of proportionate gains, respondents perceive the greatest potential gain from switching current bank accounts. However a majority of consumers responded that they did not know how much they could gain by shopping around, reducing the sample available for analysis; the implications for interpreting the model results are discussed in section 5. 
Table 3: Average Expected Search and Switch Time for Each Market (hours)

\begin{tabular}{|c|c|c|c|c|c|c|}
\hline \multirow[t]{2}{*}{ Market } & \multicolumn{3}{|c|}{ Expected search time } & \multicolumn{3}{|c|}{ Expected switch time } \\
\hline & obs & Average & Std. dev & obs & Average & $\overline{\text { Std. }}$ dev \\
\hline Electricity & 1567 & 7.30 & 15.98 & 1567 & 8.31 & 17.88 \\
\hline Mobile phone & 1653 & 5.39 & 13.26 & 1662 & 4.18 & 11.77 \\
\hline Fixed phone line & 1522 & 6.09 & 15.11 & 1551 & 5.46 & 14.34 \\
\hline National/overseas calls & 1608 & 4.47 & 12.70 & 1621 & 4.70 & 13.44 \\
\hline Broadband internet & 1884 & 1.86 & 8.32 & 1872 & 2.22 & 9.72 \\
\hline Car insurance & 1783 & 3.91 & 11.79 & 1775 & 2.42 & 9.32 \\
\hline Mortgage & 1859 & 4.52 & 13.92 & 1853 & 4.85 & 14.66 \\
\hline Current bank account & 1539 & 9.04 & 17.83 & 1543 & 10.41 & 19.62 \\
\hline Average across markets & & 5.19 & 13.87 & & 5.18 & 14.31 \\
\hline
\end{tabular}

The large standard deviations of the mean values for expected costs indicate wide variations in the time which respondents expect it will take them to search and switch. Even though the time which different consumers actually take to switch suppliers might be quite similar, particularly for groups using the same methods (for example web based comparison services), the important issue for our analysis is respondents' prior expectations. These differ quite widely even if the realisation of the costs would not do so in practice. The summary statistics of all variables across markets is shown in Table 4. 
Table 4: Summary Statistics of Variables

\begin{tabular}{|c|c|c|c|c|c|}
\hline Variables & Obs & Mean & $\begin{array}{l}\text { Std. } \\
\text { Dev. }\end{array}$ & Min & Max \\
\hline \multicolumn{6}{|c|}{ Cost and benefit measure } \\
\hline $\begin{array}{l}\text { Expected max gain } \\
\text { (exgainmax: } £ / \text { month) }\end{array}$ & 2,999 & 9.381 & $\begin{array}{l}17.18 \\
5\end{array}$ & 0 & 300 \\
\hline $\begin{array}{l}\text { Expected search time } \\
\text { (exsetime: hours) }\end{array}$ & 13,415 & 5.187 & $\begin{array}{l}13.86 \\
9\end{array}$ & 0 & 112 \\
\hline $\begin{array}{l}\text { Expected switch time } \\
\text { (exswtime: hours) }\end{array}$ & 13,444 & 5.175 & $\begin{array}{l}14.31 \\
4\end{array}$ & 0 & 64 \\
\hline
\end{tabular}

\section{Demographic variables}

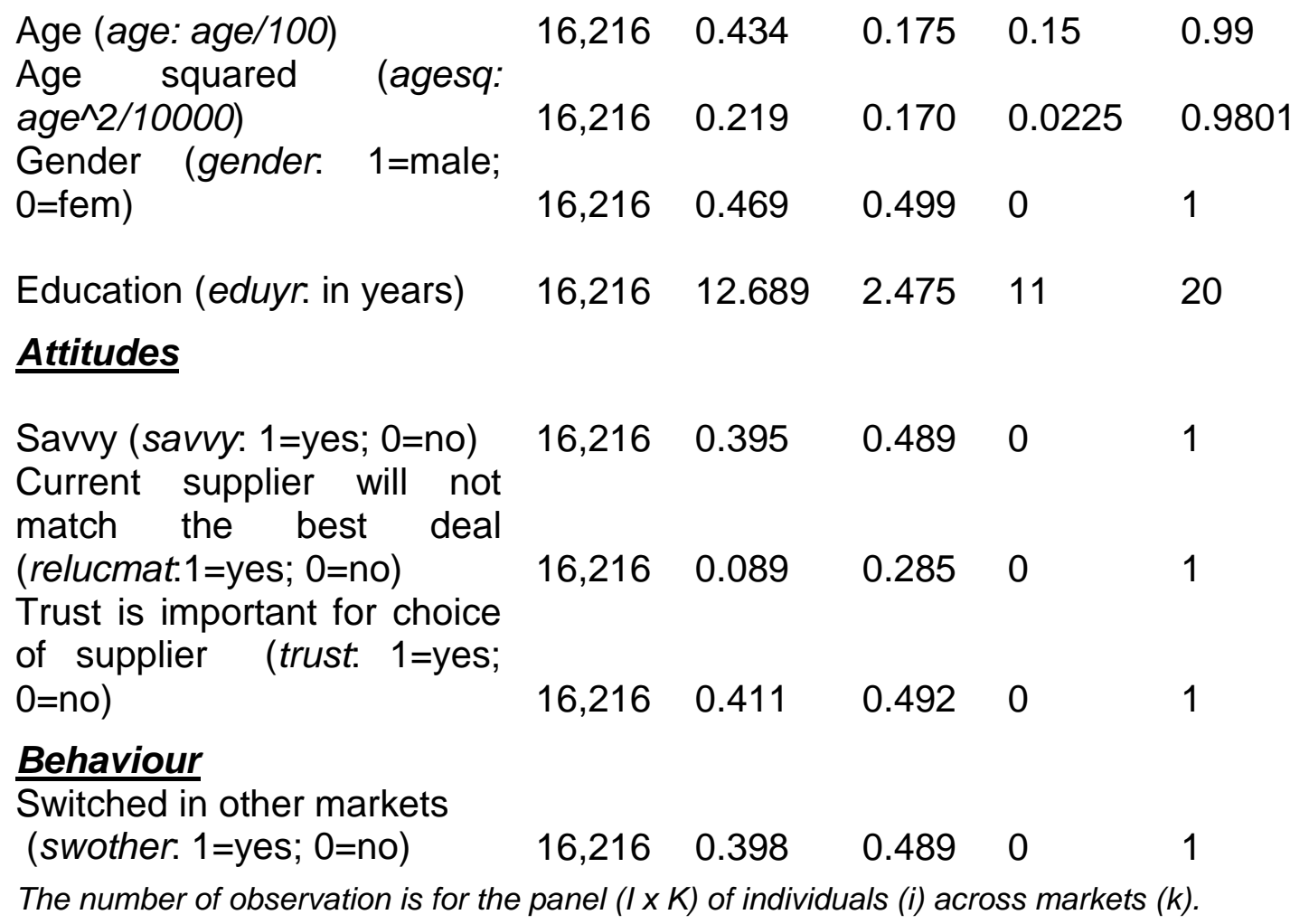

\section{Results}

The parsimonious results from the consumer utility model are shown in Table 5. Because anticipated search and switching costs were closely correlated $\left(R^{2}\right.$ $=0.66$ ) we were unable to use them together in the search equation as indicated in equation (1) above. Because search costs are more immediately relevant to the search decision, we have included these in the first stage equation. 
Table 5: Determinants of Search and Switching (default market electricity)

\begin{tabular}{|c|c|c|c|c|c|c|c|}
\hline \multirow[t]{3}{*}{ Dependent variables } & & $\begin{array}{l}(1) \\
\text { Search }\end{array}$ & & & (2) Switch & & MFX (dy/dx) \\
\hline & \multirow[b]{2}{*}{ Coef. } & \multirow[b]{2}{*}{ Std. Err. } & \multirow[b]{2}{*}{$\mathbf{Z}$} & \multirow[b]{2}{*}{ Coef. } & \multirow[b]{2}{*}{ Std. Err. } & \multirow[b]{2}{*}{$\mathbf{Z}$} & $\operatorname{Pr}($ seyes $=1$, swyes $=1)$ \\
\hline & & & & & & & $=y=0.2126$ \\
\hline Exgainmax (£/month) & -0.0095 & 0.0051 & $-1.85^{*}$ & 0.0023 & 0.0024 & 0.96 & -0.0004 \\
\hline Exsetime (hours) & -0.0027 & 0.0014 & $-1.94^{*}$ & & & & $-0.0002^{*}$ \\
\hline Exswtime (hours) & & & & -0.0032 & 0.0015 & $-2.18^{\star *}$ & $-0.0007^{* *}$ \\
\hline $\begin{array}{l}\text { Demographic } \\
\text { variables }\end{array}$ & & & & & & & \\
\hline Age (age/100) & -2.9167 & 1.0386 & $-2.81^{* * *}$ & -2.9423 & 1.0465 & $-2.81^{\star * *}$ & $-0.8722^{* * *}$ \\
\hline Agesq & 1.8769 & 1.1263 & $1.67^{*}$ & 2.6441 & 1.1511 & $2.30^{* *}$ & $0.7159^{* * *}$ \\
\hline Gender $(1=$ male $; 0=$ fem $)$ & -0.1494 & 0.0827 & $-1.81^{*}$ & -0.2926 & 0.1163 & $-2.52^{* * *}$ & $-0.0740^{* * *}$ \\
\hline Education (in years) & -0.0004 & 0.0170 & -0.03 & -0.0192 & 0.0191 & -1.01 & -0.0040 \\
\hline Savvy (1=yes; $0=$ no) & -0.1398 & 0.0790 & $-1.77^{\star}$ & -0.1107 & 0.0952 & -1.16 & -0.0352 \\
\hline $\begin{array}{l}\text { Irust } \\
(1=\mathrm{y} ; 0=\mathrm{n})\end{array}$ & 0.1313 & 0.0613 & $2.14^{\star *}$ & -0.0308 & 0.1143 & -0.27 & 0.0064 \\
\hline $\begin{array}{l}\text { Switched in other } \\
\text { markets }(1=y e s ; 0=\text { no) }\end{array}$ & -0.3157 & 0.3026 & -1.04 & 0.0694 & 0.3245 & 0.21 & -0.0146 \\
\hline Market dummies & & & & & & & \\
\hline Mobile phone & 0.1247 & 0.0878 & 1.42 & 0.1052 & 0.0913 & 1.15 & 0.0338 \\
\hline Fixed phone line & -0.3979 & 0.1035 & $-3.85^{\star \star *}$ & -0.5770 & 0.1115 & $-5.18^{\star \star \star}$ & $-0.1304^{\star * *}$ \\
\hline National/overseas call & -0.2863 & 0.1070 & $-2.68^{* * *}$ & -0.3184 & 0.1120 & $-2.84^{\star * *}$ & $-0.0824^{\star * *}$ \\
\hline Broadband internet & -0.2787 & 0.1194 & $-2.33^{\star *}$ & -0.3357 & 0.1265 & $-2.65^{\star * *}$ & $-0.0840^{* * *}$ \\
\hline Car insurance & 0.4918 & 0.0961 & $5.12^{* \star \star}$ & 0.2149 & 0.0981 & $2.19^{* *}$ & $0.0908^{* * *}$ \\
\hline Mortgage & -0.2819 & 0.1370 & $-2.06^{* *}$ & -0.2684 & 0.1633 & $-1.64^{*}$ & $-0.0730^{* *}$ \\
\hline Current Bank Account & -0.9397 & 0.1311 & $-7.17^{\star \star \star}$ & -1.0781 & 0.1481 & $-7.28^{* * *}$ & $-0.2033^{* * *}$ \\
\hline Interaction terms & & & & & & & \\
\hline Exgainmax ${ }^{*}$ mortgage & & & & -0.0057 & 0.0034 & $-1.69^{*}$ & $-0.0012^{*}$ \\
\hline Exgainmax ${ }^{*} a g e$ & 0.0293 & 0.0128 & $2.29^{* \star}$ & & & & $0.0027^{\star *}$ \\
\hline Savvy*swother & 0.3326 & 0.0945 & $3.52^{\star \star \star}$ & & & & $0.0257^{\star \star *}$ \\
\hline Swother*gender & 0.3569 & 0.1118 & $3.19^{\star \star \star}$ & 0.1963 & 0.1181 & $1.66^{*}$ & $0.0751^{* *}$ \\
\hline Swother ${ }^{\star}$ education & 0.0483 & 0.0221 & $2.19^{*}$ & 0.0546 & 0.0237 & $2.30^{* *}$ & $0.0157^{* * *}$ \\
\hline Savvy ${ }^{*}$ trust & & & & 0.1729 & 0.1049 & $1.65^{\star}$ & $0.0352^{*}$ \\
\hline Swother*trust & & & & -0.1292 & 0.1049 & -1.23 & -0.0267 \\
\hline Trust $^{*}$ gender & & & & 0.2302 & 0.1019 & $2.26^{\star *}$ & $0.0468^{* *}$ \\
\hline Constant & 0.3248 & 0.3210 & 1.01 & 0.1849 & 0.3434 & 0.54 & \\
\hline $\begin{array}{l}\text { No of obs. } \\
\text { rho }\end{array}$ & $\begin{array}{l}2388 \\
0.8412\end{array}$ & & & $\begin{array}{l}\text { Log-likel } \\
\text { Wald Ch } \\
\text { McFadd }\end{array}$ & $\begin{array}{l}\text { ood } \\
\text { (43) } \\
\text { ר's LRI }\end{array}$ & $\begin{array}{l}-2256.195 \\
443.29^{\ddagger} \\
0.145\end{array}$ & \\
\hline
\end{tabular}

N.B. ${ }^{* * *},{ }^{* * *} t$-values significant at the $10 \%, 5 \%$, and $1 \%$ levels respectively ${ }^{\ddagger}$ Chi2 -value significant at the $0.1 \%$ level. 
The results provide some support for the hypothesis that consumers' search and switching behaviour reflects an underlying model of utility maximisation. Activity is less likely if the expected time spent searching and, particularly, switching is higher. But even the latter effect is small: a one hour increase in expected time (a fifth of the average anticipated by consumers for switching) reduces the probability of activity by only seven in ten thousand. The gain anticipated from changing supplier is influential only for older respondents, and its average effect is also small - around $0.9 \%$ increase in probability for an extra expected savings of a pound per month (around a ninth of the average gains anticipated). ${ }^{7}$

The number of years spent in education which, as a proxy for income, might be expected to affect the valuation both of anticipated time and of gains, does not influence activity directly, nor interaction with either of the estimates of time commitment needed. Its only influence is in increasing the probability of switching amongst those who have switched in other markets. Such experience also increases the probability of switching amongst those who know that there is no choice of water supplier. Those who are better educated, have experience of switching and are 'savvy' about water supply are likely to be more sure of their estimates of both gain and potential costs in searching for better deals, indicating that the confidence with which a consumer provides such estimates is as influential in the decision whether to search and switch as are the values of the central estimates alone.

Age affects the probability of switching, independently of its interaction with expected gains. . The young and old are more likely to be active, with the least activity likely in the mid to late fifties, increasing after retirement age. The U-shaped age pattern for market activity is very similar to that reported in Giulietti et al (2005), Pomp et al (2005) and Sturluson (2002). Amongst consumers who do not think it important to trust suppliers and have not switched in other markets, women are around $5 \%$ more likely to be active than men, consistent with Sturluson's (2002) result; but the situation is reversed if trust of supplier is important and there is experience of switching, confirming the findings of Moshkin and Shachar (2002), who suggest that women have significantly higher switching costs.

The importance of trusting suppliers in particular markets was introduced to capture concerns about quality, which might deter consumers from switching even if they believed that there were financial benefits from doing so. Its only influence is on consumers who are knowledgeable about the water industry, when it increases the probability of activity by around $4 \%$, perhaps because these consumers are also confident in which suppliers they are able to trust.

Even allowing for the different expectations, attitudes, characteristics and experience of consumers, the probability of switching varies substantially between markets. Consumers are more likely to be active in the car insurance market than in the reference market, electricity; and less likely to search and

\footnotetext{
${ }^{7}$ In the mortgage market higher expected gains alone seem to exert a very small negative effect on the probability of switching, but this effect disappears if 3 outliers (non searchers who estimated very high potential gains) are removed.
} 
switch in all other markets except mobile phones. The market effects are large, raising the probability of activity by $9 \%$ in the car insurance market, and lowering it by $20 \%$ for current bank accounts. These market dummies do not merely reflect the difference in activity rates between markets, as shown by the descriptive statistics in Table 1. The additional activity predicted by the model in Table 5 for car insurance relative to electricity is much greater than the raw comparisons suggest; while the difference which the model predicts between activity in the mortgage and electricity markets is less than the relative proportions described in Table 1 would suggest.

Table 5 enables us to identify how each factor affects not only consumers' overall activity, but to distinguish their influence on each of their search and switching decisions. While similar factors affect the decisions to search and to switch, their influence on the two activities is not always identical. Expected gain (with age) is more likely to stimulate searching than switching; Expecting to spend an extra hour switching appears to have a greater deterrent effect than searching, but these marginal effects are not statistically significantly different from each other.

The U-shaped effect of age is similar for both search and switching. Experience of switching supplier in other markets increases the likelihood of search more than that of switching. Its influence on the decision to search equation is particularly interesting in the light of its use in other studies as a proxy for search costs themselves. Giulietti et al. (2005), who had no direct measure of expected costs, interpret experience as lowering search costs. Our results confirm that experience affects the probability of search more than that of switching. But since we have a direct measure of expected search time we are able to interpret the importance of experience of activity in other markets as increasing the confidence which consumers place in their central estimates rather than affecting those estimates directly.

\subsection{Assessment of Results}

Estimations of the model were made, selectively identifying the best use of household variables by comparing the likelihood ratios and the goodness of the fit measured by the McFadden's likelihood ratio index (LRI) as well as the AIC reported in Table A2. Goodness of fit, although relatively low, is comparable to similar studies (Giulietti et al, 2005). All our results show a high positive correlation between the residuals of the two paired equations with the rho coefficients around 0.84 , as expected, indicating that both search and switching costs are co-dependent on variables omitted from our analysis.

To obtain usable estimates of relevant variables, the observations for this analysis are restricted to a sub sample of the consumers and markets included in the original sample. One obstacle was the high non response rates to the question on expected gains. This raises concerns that the sample is biased, because those who have been active in the market are more likely to be able to estimate these gains. Using non response to this question as a dummy variable we confirmed that those who had searched and switched were indeed more likely to have responded and so be included in our sample. Overall our model predicts the probability of market activity as $21 \%$, compared with $14 \%$ of 
the entire sample who had searched and switched. While the sample is partial in this respect, the retention of $80 \%$ of consumers who have not switched in the last three years provides useful comparative information for the model. It is not clear that this partiality induces consistent bias.

For the observations included in the analysis we were concerned about potential endogeneity. Those who have searched and switched have a consistently more accurate estimate of search and switching time and potential gains. To test for this possibility we compared the expectations across customers who were active and inactive in each market (Table A4 in appendix). We found that consumers who had switched or searched provided lower estimates for both anticipated gains and expected search and switch time than their inactive counterparts. This provides some comfort that any endogeneity operates in opposite directions; if the searchers/switchers have knowledge of 'true' values, inactive customers are underestimating both the positive and negative aspects.

The confidence with which consumers estimate potential gains and costs exerts a positive effect on search and switching. Our model suggests that variables which would increase confidence (switching in other markets, knowledge about the water industry, level of education) are important in predicting increased market activity. The effect of experience in other markets on expectations is particularly interesting. Those who have switched elsewhere predict higher levels of search and switching time, and of gains, so the influence of experience does not seem to be through these central estimates. Rather this provides support for the role of previous switching in providing confidence for each consumers' predictions, and the positive effect that this has on activity. Confidence may also be a factor in the market differences, where greater certainty in some markets might reflect advertising or information campaigns. The inclusion of these other variables, which are designed to capture consumers' confidence in their estimates and which result from switching in other markets, should alleviate the endogeneity problem somewhat.

For all these reasons the results should be interpreted as a general indication of which factors affect consumer activities, and the direction of their influence, rather than as precise measures of individual coefficients or marginal effects. Despite these 'caveats', the model is sufficiently robust to indicate that consumer activity within this sample seems to be explained well by a model based on conventional maximisation of consumer utility. However the process is clearly more complex than a 'straight' trade-off between expected costs and benefits, and activity in the market depends on many aspects of consumers' characteristics and experience beyond a pure monetary model. Some are demonstrated in the variables included in the model; and the high value of rho demonstrates that many factors common to search and switching have been omitted. 


\section{Policy Implications and Conclusions}

This is the first study of which we are aware in which consumers' own estimates of potential gains and time expenditure have been used as potential determinants of their activity in the market. Most previous studies have used extrinsic estimates of the gains available to consumers, and demographic variables as proxies for the search and switching costs which would be incurred. One advantage of our approach is that we are able to separate the effect of demographic and other characteristics as direct influences from their role as representatives of the time which consumers expect to spend searching and switching.

Consumers' decisions to become active in a market can be partially explained by a model of utility maximisation. This provides some justification for the optimism of Competition Authorities in imposing information remedies. Those who had switched had higher estimates (with greater variation between consumers) for both search and switching costs: inactivity is not due to overestimates of the time taken in either search or switching. They also had higher estimates (and higher inter-consumer variance) for anticipated gains. So inactive consumers might be motivated by greater potential rewards, though the effect of increasing the mean expectation would be very small.

However the influence of a consumer's expected gains and costs, even when these are directly measured, provide only a small part of the explanation for the probability that they will be active in a market. The confidence with which consumers predict their likely gains and costs seem to be much more influential in determining whether or not they will switch. Such motivation is consistent with the wish to reduce their 'regret' in switching decisions. As in previous studies we find that experience of switching in other markets exerts a major and positive influence, which we are able to interpret as reducing the variation of a consumer's estimate, rather than affecting its central value. To encourage activity in any one market, competition authorities need to provide consumers with good information, of which consumers are confident, about the likely costs and benefits. This will provide positive externalities for other markets, building further confidence through experience.

Other positive influences on switching include knowledge about which markets are competitive and level of education, indicating the importance of good general education about consumer matters and opportunities. Authorities who wish to punish inappropriate firm behaviour by publicising bad experiences of switching through a 'name and shame' process may face a conundrum, if such publicity lowers consumer confidence and deters market activity. While age and gender both influence activity, there are no obvious lessons for targeting information or other campaigns at particular demographic groups.

The significant and substantial differences between markets do suggest differential approaches. All the markets included in this study are subject to sector regulation: from the Office of Gas and Electricity Markets (electricity); the Office of Telecommunications (mobile and fixed line phone services and broadband); or from the Financial Services Authority (car insurance, mortgages and bank accounts). The greatest propensity to switch is in the car 
insurance market, though the influence of anticipated savings from switching is particularly small in this market. Car insurance is the only market in our sample where annual reminders for renewal are required, even if the consumer need take no action to stay with the current supplier. Such reminders seem to prompt some consumer activity, and some competitors target advertising at the time of contract renewal. Regulators might wish to consider imposing similar reminders in other markets, though they would need to balance potential gains against the cost of the exercise. The greater influence of savings on activity in mobile phones may indicate response to high profile advertising, a function more appropriate for firms than authorities. The reduced probability of activity for fixed line products and in current bank accounts, compared with electricity, confirms that the lower level of switching in these markets is not explained by differences in the expected gains or costs, or in the other personal characteristics and experience variables included in the regression; consumers are more reluctant to be active in these markets, regardless of these factors. To increase activity here, authorities need to explore further the particular features of these markets which render searching and switching less attractive. In contrast, the lower level of switching for mortgages and broadband (well under half that reported for electricity) are explained by the expected gains and costs and other factors, rather than by differences in the markets themselves. In this case, any remedial action would be less effectively targeted to market based campaigns unless they specifically affected these other factors.

In terms of addressing the search and switch activities directly, there is weak evidence that consumers may be more deterred by switching than by search costs, but the difference is not statistically significant. The factors affecting each decision are broadly similar, so there is no clear indication that market activity would be improved by targeting one process rather than the other. Remedies to increase knowledge and confidence, as identified above, should address both the search and the switching processes.

We conclude that while a model of utility maximisation provides some explanation of consumers' market activity, the influence of expected gains and time involved is relatively small. Many other factors, in particular the confidence with which consumers hold their estimates of gains and costs, are important influences. And much remains unexplained, suggesting that consumers both maximise utility and display 'behavioural' characteristics in deciding whether to search for better deals and switch providers. The use of informational remedies by competition Authorities does not seem misplaced. The importance of consumer confidence, the role of other factors and the differences between markets indicate the need to tailor action carefully to each situation. 


\section{References}

Agarwal S., Chomsisengphet S., Liu C. and Souleles N.S. (2006). "Do Consumers Choose the Right Credit Contracts?" Federal Reserve Bank of Chicago Working Paper 2006-11.

Baye, M. R., Morgan, J. and Scholten, P. (2006). "Information, Search and Price Dispersion." in T. Hendershott (ed.), Handbook on Economics and Information Systems 1, Amsterdam: Elsevier.

Chen, P. Y. and Hitt, L. M. (2002). "Measuring Switching costs and the Determinants of Customer Retention in Internet-Enabled Business: A Study of the Online Brokerage Industry." Information Systems Research, 13(3), pp.255-274.

Competition Commission, 2003a, Veterinary Medicines, April.

Competition Commission, 2003b, Extended Warranties on Domestic Electrical Goods, September.

Competition Commission, 2006a, Store Card Credit Services, March.

Competition Commission, 2006b, Domestic Bulk Liquefied Petroleum Gas, June.

Competition Commission, 2006c, Home Credit, November.

Competition Commission, 2007, Northern Irish Personal Banking, May.

DellaVigna, S. (2007). "Psychology and Economics: Evidence from the Field", National Bureau of Economic Research Working Paper 13420, September.

Economides N., Seim K. and Viard V.B. (2006). "Quantifying the Benefits of Entry into Local Phone Service" NET Institute Working Paper \#05-08, August.

Ellison, G. (2006). "Bounded Rationality in Industrial Organisation," in R. Blundell, W. Newey and T. Persson (eds.), Advances in Economics and Econometrics: Theory and Applications, Ninth World Congress, Cambridge: Cambridge University Press.

Farrell, J. and Klemperer, P. (2006). "Coordination and Lock-In: Competition with Switching Costs and Network Effects." mimeo. 
Garrod, L., Hviid, M., Loomes, G., Waddams Price, C. (2008). Assessing the effectiveness of potential remedies in consumer markets, Office of Fair Trading (forthcoming).

Giulietti, M., Waddams Price, C. and Waterson M. (2005). "Consumer Choice and Competition Policy: A Study of UK Energy Markets." Economic Journal, 115(506), pp.949-968.

Greene, W. H. (2007). Econometric Analysis, $6^{\text {th }}$ ed., New Jersey: Prentice Hall.

Hong, H. and Shum, M. (2006). "Using Price Distributions to Estimate Search Costs." RAND Journal of Economics, 37(2), pp.257-275.

Hortacsu, A. and Syverson, C. (2004). "Product Differentiation, Search Costs and Competition in the Mutual Fund Industry: A Case Study of S\&P 500 Index Funds." Quarterly Journal of Economics, 119(2) pp.403-456.

Johnson, E. J., Moe, W. W., Fader, P. S., Bellman, S. and Lohse G. L. (2004). "On the Depth and Dynamics of Online Search Behaviour." Management Science, 50(3), pp.299-308.

Kim, M., Kliger, D. and Vale, B. (2003). "Estimating Switching Costs: The Case of Banking." Journal of Financial Intermediation, 12(1), pp.25-56.

Kiser, E. K. (2002). "Predicting Household Switching Behavior and Switching Costs at Depository Institutions." Review of Industrial Organisation, 20(4), pp.349-365.

Klemperer, P. (1995). "Competition When Consumers Have Switching Costs: An Overview with Applications to Industrial Organisation, Macroeconomics and International Trade." Review of Economic Studies, 62(4), pp.515-539.

Lambrecht A. and Skiera B. (2006). "Paying Too Much and Being Happy About It: Existence, Causes and Consequences of Tariff Choice Biases" Journal of Marketing Research, vol. XLIII, pp. 212-223, May.

Miravete E.J. (2003). "Choosing the Wrong Calling Plan? Ignorance and Learning" American Economic Review vol. 93(1) p.297-310

Moorthy, S., Ratchford, B. T. and Talukdar, D. (1997). "Consumer Information Search Revisited: Theory and Empirical Analysis." Journal of Consumer Research, 23(4), pp.263-277.

Moraga-González, J. L. and Wildenbeest, M. R. (2006). "Maximum Likelihood Estimation of Search Costs." Tinbergen Institute Discussion Paper, TI2006-019/1. 
Moshkin, N. V. and Shachar, R. (2002). "The Asymmetric Information Model of State Dependence." Marketing Science, 21(4), pp.435-454.

Pomp, M., Shestalova, V. and Rangel, L. (2005). "Switch on the Competition: Causes, Consequences and Policy Implications of Consumer Switching Costs." CPB Working Paper, No.97.

Rotemberg, J. J. (2008). "Behavioral Aspects of Price Setting, and their Policy Implications", National Bureau of Economic Research Working Paper 13754, January

Salies, E. and Waddams Price, C. (2004). "Charges, Costs and Market Power in the Deregulated UK Electricity Retail Market." The Energy Journal, 25(3), pp.19-35.

Shy, O. (2002). "A Quick and Easy Method for Estimating Switching Costs." International Journal of Industrial Organisation, 20(1), pp.71-87.

Silk, T. (2006) "Getting Started Is Half the Battle: The Influence of Deadlines and Effort on Consumer Self-Regulation to Redeem Rewards", Working Paper, University of British Columbia.

Simon, H. (1991). Models of My Life, Basic Books Inc., New York.

Sturluson, J. T. (2003). "The Importance of Consumer Search and Switching Costs for Competition in Electric Power Retailing" in Topics in the Industrial Organization of Electricity Markets, Stockholm EFI Publication No.614.

Waterson, M. (2003). "The role of consumers in competition and competition policy," International Journal of Industrial Organization, 21(2), 129-150.

Wilson, C. M. (2006). "Markets with Search and Switching Costs" CCP Working Paper 06-10.

Wilson, C. M. and Waddams Price, C., (2007). "Do Consumers Switch to the Best Supplier?", Centre for Competition Policy Working Paper 07-6, University of East Anglia. 
Appendix:

Questions asked in survey

Q1. In your area, do you have choice of more than one provider for the following products? READ OUT

QA. Firstly, could you tell me if you are involved solely, jointly or not at all in the decision of which supplier to use for any of these services or products?

Q2. SHOWCARD B Which of the following does your household currently have and pay for?

Q4. SHOWCARD C Using the words on this card, how important or unimportant is it to you to trust your provider for the following products?

\begin{tabular}{|c|c|c|c|c|}
\hline $\begin{array}{l}\text { Very } \\
\text { im- } \\
\text { portant }\end{array}$ & $\begin{array}{l}\text { Fairly } \\
\text { im- } \\
\text { portant }\end{array}$ & $\begin{array}{c}\text { Neither } \\
\text { im- } \\
\text { portant } \\
\text { nor } \\
\text { unim- } \\
\text { portant }\end{array}$ & $\begin{array}{c}\text { Fairly } \\
\text { unim- } \\
\text { portant }\end{array}$ & $\begin{array}{c}\text { Very } \\
\text { unim- } \\
\text { portant }\end{array}$ \\
\hline
\end{tabular}

Q5. Have you looked around for a new provider for any of the following products at any time in the last three years, that is, since May 2002?

Q11 Apart from when moving home, have you switched provider of any of these products in the last three years, that is, since May 2002? READ OUT

\section{ASK ALL SWITCHED ANY}

Q15 Please tell me how much time you spent searching around and looking for the necessary information before you switched each relevant product area?

$$
\begin{array}{ccccccccc}
\text { No } & \begin{array}{c}
\text { Up to } \\
\text { time at }
\end{array} & \begin{array}{c}
1 \text { to } 3 \\
\text { an } \\
\text { all }
\end{array} & \begin{array}{c}
4 \text { to } 8 \\
\text { hour }
\end{array} & \begin{array}{c}
\text { About } \\
1 \text { day }
\end{array} & \begin{array}{c}
2 \text { to } 3 \\
\text { days }
\end{array} & \begin{array}{c}
4 \text { to } 6 \\
\text { days }
\end{array} & \begin{array}{c}
\text { A } \\
\text { week } \\
\text { or } \\
\text { more }
\end{array} & \begin{array}{c}
\text { Don't } \\
\text { know }
\end{array}
\end{array}
$$

IF ANY TIME SPENT SEARCHING AT Q15

Q17 Would you say it took more time than expected, less time than expected or as long as you expected to search for information on ....?

$$
\begin{array}{cccc}
\begin{array}{c}
\text { More } \\
\text { time than } \\
\text { expected }
\end{array} & \begin{array}{c}
\text { As } \\
\text { expected }
\end{array} & \begin{array}{c}
\text { Less time } \\
\text { than } \\
\text { expected }
\end{array} & \begin{array}{c}
\text { Don't } \\
\text { know }
\end{array} \\
& &
\end{array}
$$

\section{ASK ALL SWITCHED ANY}

Q23 How much of your own time did it take to switch PRODUCT AREA after you made a decision? 
ASK ALL NOT SWITCHED BUT SEARCHED IN ANY AREA (Q27)

Q29 How much time did it take you to search for the necessary

information on ...?

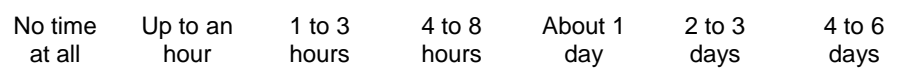

\section{ASK ALL NOT SWITCHED BUT SEARCHED IN ANY AREA}

Q33 How long do you think it would have taken of your own time to switch once you had all the necessary information for switching

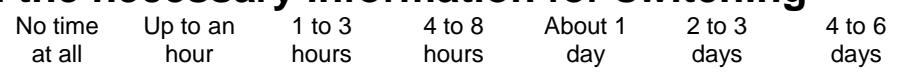

\section{ASK ALL NON-SWITCHERS WHO HAVE NOT SEARCHED}

Q35 How much of your own time did you think it would take you to find enough information to decide whether and to whom to switch

$\begin{array}{ccccccc}\text { No time } & \text { Up to an } & 1 \text { to } 3 & 4 \text { to } 8 & \text { About } 1 & 2 \text { to } 3 & 4 \text { to } 6 \\ \text { at all } & \text { hour } & \text { hours } & \text { hours } & \text { day } & \text { days } & \text { days }\end{array}$

ASK ALL NON-SWITCHERS WHO HAVE NOT SEARCHED

Q36 Once you have found all the necessary information to choose a new supplier, how much of your own time do you think it would take to switch

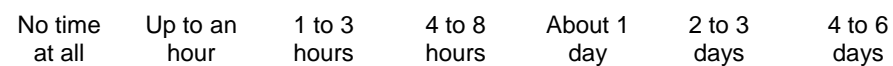

\section{ASK ALL RELEVANT}

Q46 How much is the most you think you could save per month if you shopped around for... ? READ OUT PRODUCT AREAS

Construction of expected time spent searching and switching

The expected search time (exsetime) and the expected switching time (exswtime) are constructed from different questions for different consumer groups according to the table below. Table A4 below compares the expected search and switch times for active and inactive consumers.

Table A1: Construction of Expected Search and Switching Time

\begin{tabular}{|l|l|l|l|l|l|}
\hline $\begin{array}{l}\text { Consumer } \\
\text { group }\end{array}$ & $\begin{array}{l}\text { time spent } \\
\text { searching? }\end{array}$ & $\begin{array}{l}\text { more or } \\
\text { less than } \\
\text { expected? }\end{array}$ & $\begin{array}{l}\text { expected } \\
\text { search time } \\
\text { ex ante? }\end{array}$ & $\begin{array}{l}\text { switching } \\
\text { time ex } \\
\text { post? }\end{array}$ & $\begin{array}{l}\text { expected } \\
\text { switching } \\
\text { time ex } \\
\text { ante? }\end{array}$ \\
\hline $\begin{array}{l}\text { Searched \& } \\
\text { switched }\end{array}$ & Q15 & Q17 & $\begin{array}{l}\text { Adjusted } \\
\text { Q15 by one } \\
\text { scale down } \\
\text { or up } \\
\text { according to } \\
\text { Q17. }\end{array}$ & Q23 & \\
\hline
\end{tabular}




\begin{tabular}{|l|l|l|l|l|l|}
\hline $\begin{array}{l}\text { Searched } \\
\text { but } \\
\text { not } \\
\text { switched }\end{array}$ & Q29 & & Q35 & Q33 \\
\hline $\begin{array}{l}\text { Not } \\
\text { searched } \\
\text { nor } \\
\text { switched }\end{array}$ & & Q & & Q36 \\
\hline $\begin{array}{l}\text { Not } \\
\text { searched } \\
\text { (Q15=0) } \\
\text { and } \\
\text { switched }\end{array}$ & 0 from Q15 & Q17 & $\begin{array}{l}\text { Adjusted, but } \\
\text { not } \\
\text { downwards }\end{array}$ & Q23 & \\
\hline
\end{tabular}

Table A2: The Akaike's Information Criterion (AIC) for Model Selection

\begin{tabular}{|c|c|c|c|c|}
\hline & Log Likelihood & \# of parameters & Sample size & AIC \\
\hline Full base model (M0) & -2218.8731 & 126 & 2388 & 1.9647 \\
\hline $\begin{array}{l}\text { Reduced model 1: dropped all } \\
\text { insignificant interaction terms }(p>0.1)(\mathrm{M} 1) \\
\text { Reduced model 2: dropped all }\end{array}$ & -2254.1950 & 44 & 2388 & 1.9256 \\
\hline insignificant interaction terms $(p>0.1)(M 2)$ & -2259.0816 & 40 & 2388 & 1.9264 \\
\hline
\end{tabular}

The above table summarises the model selection process by a general-tospecific approach. The AIC figures suggest the model M1 is the best fit amongst the various models reduced from the full base model (M0). The reduced models $\mathrm{M} 1$ and $\mathrm{M} 2$ were constructed by dropping statistically insignificant variables. Dropping a variable(s) in this way allows identification of the trade-off between the Log-likelihood ratio and the number of. The turnaround in the AIC between the models M1 and M2 indicate that further reduction is not beneficial.

Table A3: The Interaction Terms Used in the Full Base Model

$\begin{array}{cccccccc}\text { exgainm } & \text { exseti } & \text { exswti } & \text { ag } & \text { gend } & \text { ed } & \text { sav } & \text { tru } \\ \text { ax } & \text { me } & \text { me } & \text { e } & \text { er } & u & \text { vy } & \text { st }\end{array}$

\section{Demographic}

Age

Gender

Edu

$\begin{array}{lll}x & x & x \\ x & x & x \\ x & x & x\end{array}$

\section{Attitudes}

Savvy

Trust

$\begin{array}{lllllll}x & x & x & x & x & x & \\ x & x & x & x & x & x & x\end{array}$

\section{Behaviour}

Swother

$x \quad x$

$\mathrm{x}$

Market

Electricity

x $\quad x \quad x$


Mobile

Fixed phone

Nat'//ovreseas call

rates

Broadband

internet

Car insurance

Mortgage

Current bank

account $x \quad x \quad x$

$x \quad x \quad x$

X $\quad \mathrm{X}$

$x \quad x \quad x$

$x \quad x \quad x$

$x \quad x$

X $\quad x$


Table A4: Expectation Differences Between Active and Inactive Consumers

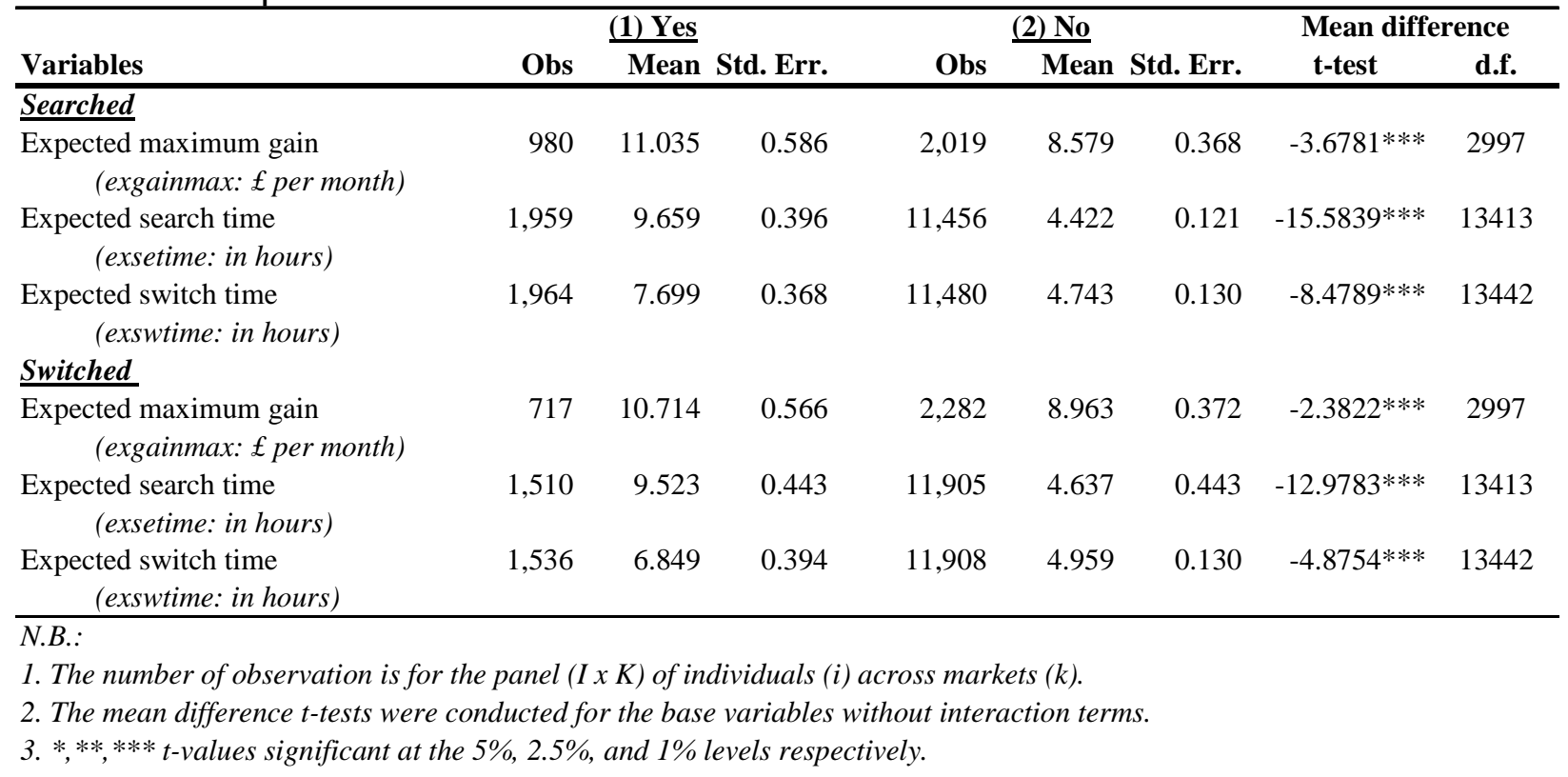

Table A4 shows that there are differences in the expectation of gains and costs between active and inactive consumers (e.g. searchers vs. nonsearchers), with inactive consumers estimating lower expected gains and costs. 